\title{
Towards Sustainable Agriculture in Chile, Reflections on the Role of Public Policy
}

\author{
Oscar Melo ${ }^{1}$, Nadia Báez Quiñones ${ }^{2}$, and Daniela Acuña ${ }^{3}$ \\ ${ }^{1}$ Pontificia Universidad Católica de Chile, Facultad de Agronomía e Ingeniería Forestal, Department of \\ Agricultural Economics. Avenida Vicuña Mackenna 4860, Macul, Santiago, Chile. \\ ${ }^{2}$ Institute of Animal Science, Department of Pasture Science. Carretera Central km 47 1/2, AP 24, San José \\ de Las Lajas, Mayabeque, Cuba. \\ 3. Ministry of Agriculture, Office of Agricultural Studies and Policies, ODEPA, Department of \\ Sustainability and Climate Change. Teatinos 40, 8th Floor, Santiago, Chile.
}

\begin{abstract}
O. Melo, N. Báez Quiñones, and D. Acuña. 2021. Towards Sustainable Agriculture in Chile, Reflections on the Role of Public Policy. Int. J. Agric. Nat. Resour. 186-209. Given the increasing demand for agricultural products and the environmental degradation that current agricultural practices generate, there is an urgent need to change the activity. Sustainable agriculture emerges as an attractive alternative to mitigate the adverse effects of the activity on the environment, increase its resilience to global change, and increase the current population's quality of life without sacrificing that of future generations. However, identifying effective policies that can achieve these goals remains elusive. In Chile, this sector has been one of the drivers of growth and poverty reduction but still faces many environmental and social challenges, and there is a growing public demand for achieving sustainability from an economic, environmental, and social perspective. Public and private institutions have made relevant efforts to increase Chilean agriculture sustainability. However, the need to transition towards sustainable agriculture is still not recognized by all stakeholders. In this article, we review current challenges and policies to achieve a more sustainable agriculture in Chile
\end{abstract}

Keywords: Forestry and livestock sector, sustainability.

\section{Introduction}

Conventional agriculture, based on the high use of inputs, has increased environmental degradation. This activity occupies, worldwide, the second place in Greenhouse Gases (GHG) emissions, contributing $18 \%$ of all emissions (FAO, 2014). In addition, it has been accompanied by

Received Aug 02, 2021. Accepted Dec 21, 2021 Corresponding author: omelo@uc.cl other environmental and social consequences, such as water depletion, soil degradation, loss of biodiversity, ecosystem simplification, and population decline in rural areas, among others (Amekawa, 2011; FAO, 2018). However, it is not agriculture itself responsible for these problems, but how it has been practiced in recent decades (Velten et al., 2015).

As the global population and household incomes are expected to double by 2050 , food and energy 
consumption will also expand significantly. Climate change is expected to adversely affect crop yields and water availability by that year. As a result, efforts to mitigate climate change have drawn attention to the potential of agriculture to reduce GHG emissions, produce bioenergy, and increase soil carbon stocks (Khanna et al., 2018) and increase production to continue feeding the world population more efficiently and equitably.

In this context, there is a need for policies that promote a transformation of current agriculture towards an economically, socially, and environmentally sustainable activity (Gökkür \& Sinav, 2020). Thus, the transition towards sustainable agriculture appears not only necessary but also inevitable as society raises its expectations regarding the sector's performance.

Sustainable agricultural development is widely recognized as a critical component of a strategy to combat poverty and environmental degradation. However, it remains an elusive goal, especially in many of the poorest regions of the world (Antle \& Diagana, 2003). On the other hand, in more developed countries, policies have centered around economic support and more recently started addressing environmental problems (Baylis et al., 2008).

The economic development of agriculture in Chile has been an internationally recognized success story, bringing economic benefits both within the sector and the broader economy (Agosin \& BravoOrtega, 2012; Barham et al., 1992; Lebdioui, 2019; Meller \& Saéz, 1995; Negoita \& Block, 2012). The agricultural and forestry sector, represented $3 \%$ of the national GDP in 2020. This number has remained relatively constant for the past 25 years; it varied between $2.8 \%$ and $3.5 \%$, but it was also $3 \%$ in $1996 .{ }^{1}$ This means that during this period the sector has grown, on average, at the same rate as the rest of the Chilean economy, at a rate of $3.4 \%$ per year. Moreover, when the sector's forward and backward productive linkages are added, its contribution to national GDP doubles (Foster and Valdés, 2015).
Chile's development model has been criticized for mainly depending on copper exports; something only challenged by the agriculture and forestry sector. In 2019, agriculture and forestry ranked second in exports, representing $30.4 \%$ of national exports (including industrial products directly obtained from the sector like wine and paper), below mining with $54.7 \%$ and above the industrial sector (excluding industrial activities form agriculture, forestry and mining) with 10.6\% (Central Bank of Chile, 2020). This essential participation in economic activity is also reflected in its contribution to employment, representing $10 \%$ of the national total. However, in some regions of the country, such as Maule and O'Higgins, where agricultural GPD represents $13.1 \%$ and $12.5 \%$, direct agricultural employment represented $28.8 \%$ and $26.2 \%$, respectively (ODEPA, 2019). This has had a crucial impact on overcoming poverty in rural areas, but has also contributed to its reduction in urban areas (de Ferranti et al., 2005; Bravo-Ortega \& Lederman, 2005; Valdés \& Foster, 2010).

The development of the sector over the last 40 years has been the result of the country's political and economic stability and specific policies that have supported this development. Among these policies are the security of land and water rights ownership, trade liberalization, phytosanitary protection, trade agreements, infrastructure and technology adoption, exports promotion and innovation support, among other support policies for the sector (Agosin \& Bravo-Ortega, 2012; Meller \& Saéz, 1995; Anríquez \& Melo, 2018; Valdés, 1994). The latter include subsidies for forestry plantations, irrigation, and fertilization, among other public policies. This institutional and public policy environment has enabled entrepreneurs of different sizes to expand the sector's activity, provide employment and bring economic activity to otherwise depressed areas.

This growth has brought an expansion of the agricultural frontier and an intensification of the activity. Although Chilean land-use statistics 
available at the national level are incomplete and outdated, they show that between 1997 and 2007, the agricultural (including fallow land) and livestock areas decreased by $9 \%$ and $17 \%$, respectively. On the other hand, the area under forest plantations increased by $23 \%$ (Echeñique \& Romero, 2009). This decrease in total cultivated area is accompanied by an intensification, moving from extensive (e.g., wheat) to more intensive crops (e.g., fruits). For example, between 19972007 , the orchards area grew by $100 \%$ in the Coquimbo region, nearly $50 \%$ in the Valparaíso and Maule regions, $36 \%$ in O'Higgins, and $20 \%$ in the Metropolitana region. However, this growth seems to be slowing down, because from the year 2007 to the 2017/2018 season, Coquimbo, Valparaiso, and the Metropolitana regions reduced their fruit area, and in Maule and O'Higgins, it only increased by $22 \%$ and $9 \%$, respectively (Ginocchio et al., 2019). Agricultural expansion into areas with no previous productive use represented a small fraction of the total area but, in some cases, affected fragile ecosystems. However, this intensification has led to considerable use of productive resources, such as water, by shifting from rainfed to irrigated crops, thus, in general, having a larger ecological footprint.

As a result of economic development, increased education, globalization, and advances in information and communication technologies, society has increased its demands on the environmental attributes of agricultural products, including their production process and the marketing chain in general. However, these demands can be very different in different countries. Globally, consumers are increasingly demanding more information about the characteristics and attributes of food, which is partly due to rising incomes and knowledge. For example, they are interested in the origin, whether they are organically produced or from genetically modified organisms (GMO), come from fair trade, are healthy, locally produced, or preserve ecosystem services (including aesthetic services, habitats, biodiversity, carbon storage, and recreation; Khanna et al., 2018). In recent years, legislative actions and civil society initiatives have focused on soft-drink taxes, animal welfare, school snacks health, labels on GMOs, and the origin of meats. Innovation has brought a new range of food and agricultural technologies based on biotechnology, irradiation, and pesticides to improve food safety, increase productivity and reduce environmental impact. These changes are emerging alongside various trends that have attracted public concern related to public health, animal wellbeing, and the environment (Lusk \& McCluskey, 2018). Health, convenience, pleasure, sustainability, and authenticity are the top five trends in international food and beverage consumption that have been identified and may affect the agricultural industry in many areas such as production, consumption, investment, and market orientations in the future (Gökkür \& Sinav, 2020).

All these trends and changes lead to questions regarding the future of the sector in Chile: will it continue growing at the rates it has done so far, or are new approaches required to ensure the continuity of its development and the contributions it makes to society? How can it achieve this goal while addressing the environmental and social demands, as well as a growing international competition? This essay presents an analysis of the sustainability of Chile's agricultural and forestry sector, reviewing long-term challenges and current policies, and offering lessons that can help Chile transition to a more sustainable sector. This analysis can also help other countries pursuing sustainable agricultural development reflect on the Chilean experience and apply the relevant lessons to their transitions.

This introduction is followed by a discussion of the concept of sustainability in agriculture, then the main sustainability challenges facing agriculture in Chile are presented. The policies relevant to the sector's sustainability are reviewed, and recommendations for action are made. 


\section{The concept of sustainable agriculture}

The concept of sustainable agriculture has gained momentum since the definition of sustainable development in the Brundtland report in 1987. There has been extensive discussion on how to define it, but in general, the definitions consider the environmental, economic and social dimensions, the capacity to perpetuate the services provided, and the harmony with natural biological cycles. Some examples of definitions of this concept are presented below.

According to the Food, Agriculture, Conservation, and Trade Act of 1990 (1990) sustainable agriculture is:

"an integrated system of plant-animal production practices in a site-specific application that will continue to: (a) meet human needs for food and fiber; (b) enhance environmental quality; (c) make efficient use of nonrenewable resources and appropriately integrate natural biological cycles and controls; (d) maintain the economic viability of farm operations; and (e) enhance the quality of life for farmers and society as a whole."

This definition uses the three key dimensions, but it does not explicitly include a concern for the needs of future generations. The Food and Agriculture Organization of the United Nations (FAO) postulates that sustainable agriculture has five main attributes: it conserves resources (land, water, plants and genetic resources), does not degrade the environment, is technically appropriate and is economically and socially acceptable (Lee, 2005). The definition given by this organization, establishes that in order to be sustainable:

"agriculture must meet the needs of present and future generations, while ensuring profitability, environmental health, and social and economic equity. Sustainable food and agriculture contributes to all four pillars of food security - availability, access, utilization and stability - and the dimensions of sustainability (environmental, social and economic)."’

The idea of meeting current generation demands without sacrificing those of future generations is not easy to implement. Are all current generation demands legitimate?, how much more affluent (or more impoverished) will the future generations be? for example, in terms of access to technology not available today. Brodt et al. (2011) suggest linking future generations' demands with the idea that sustainable agriculture should care for the long-term stewardship of the natural environment and sentient beings.

Other definitions of sustainable agriculture have given more detail for each of the three main components (environmental, social, and economic). For example, Gastó et al. (Gastó et al., 2009) suggest distinguishing sustainability from natural resource conservation and propose 12 specific dimensions that need to be addressed.

Although many of the existing definitions have some common ideas, there is no consensus in the literature, and, on the contrary, different currents of thought give it their own emphasis, sometimes responding to their interests (Velten et al., 2015). Sustainable agriculture is understood as a goal or ideal to be achieved, but this ideal could also change over time, and be different for different groups of people or societies. There is an extensive debate as to what these goals should be and how they should be achieved, in many cases definitions are ambitious and try to address many dimensions becoming less practical. To a greater or lesser degree, the three dimensions (environmental, social, and economic) in their present and future state are the conceptual basis for almost any approach to sustainability. However, there is an essential distinction between these dimensions.

\footnotetext{
${ }^{1}$ http://www.fao.org/sustainability/
} 
On the one hand, environmental and social aspects respond to society's demands on these two aspects. These demands may take the form of regulations, market requirements, voluntary mechanisms or aspirations expressed by other means, which translate into pressure for their incorporation into the activity. However, although linked to the social and environmental dimensions, economic sustainability implies the capacity to at least compensate for the cost of inputs and investments needed for production. In other words, economic sustainability is not only dependent on society's market and non market demands, but also on the technological and agroclimatic conditions and, in this sense, is different from the other two dimensions. Therefore, sustainable agriculture would respond to environmental and social demands that may change over time and according to the context and to its economic viability, which does not respond directly to the socio-environmental preferences of the population. ${ }^{2}$

Thus, sustainable agriculture does not consist of a set of management practices, technologies, or a particular type of agriculture but of a vision or set of goals. However, the literature has proposed different strategies and areas of action to achieve these goals (Velten et al., 2015). These actions can be at the farm level, at the production chain level, and the final consumer of agricultural products and their derived processed products and disposal requirements. Moreover, to achieve these goals, different actions may be necessary for different situations or locations. For example, the sociodemographic characteristics of farmers and the agro-climatic attributes of their farms influence the adoption of sustainable agricultural practices (Filson, 1996). However, many times the proposed measures do not have an integrated view and only address one dimension, neglecting the effect on the others. For example, by promoting strict environmental measures that may affect the livelihoods of small-scale farmers or by subsidizing activities without considering their environmental and social impacts.

\section{Sustainability challenges in agriculture and forestry in Chile}

The Chilean agricultural and forestry sector faces significant challenges in order to achieve sustainability. A metric to evaluate its progress and compare with other countries are the United Nations Sustainable Development Goals (SDGs) that propose a list of targets, and corresponding indices, to guide actions towards sustainable development. ${ }^{3}$ The SDGs are the continuation of the Millenium Development Goals (MDGs) seeking to continue progress on the goals met, as well as to achieve those goals that were not achieved. The SDGs seek that all countries commit to this development agenda, as is the case of Chile. Some of the SDGs proposed are closely linked to the goal of sustainable agriculture. Given that it is a sector whose actions are based on natural resources, goals such as SDG 6 Clean Water and Sanitation, SDG 15 Life of Terrestrial Ecosystems, or SDG 13 Climate Action have a direct relationship with the way in which the sector is developed. But there is also a close relationship with those goals linked to food and nutrition (SDG 2), the end of poverty (SDG 1), in particular the role of agriculture in reducing rural poverty, and decent work (SDG 8), among others. For both the public and private sectors, the challenge is to strengthen the initiatives that contribute to the SDGs, and generate new programs to fill those areas where there are still gaps (Acuña, 2018).

A diagnosis on Chile's environmental performance, conducted by the OECD (2016), indicates that the

\footnotetext{
${ }^{2}$ Socio-environmental preferences can also be expressed through markets and regulations, indirectly affecting the economic viability of agricultural activity.

${ }^{3} \mathrm{http}$ ///www.un.org/sustainabledevelopment/es/objetivos-de-desarrollo-sostenible/
} 
country's economic activities make intensive use of natural resources and are highly dependent on them, as is the case of the agriculture and forestry sector. The OECD report also identified a high scarcity and contamination of water resources, which affects the productivity of this sector. In addition, the report finds that there is a reduction of biodiversity and a high vulnerability to climate change.

These type of assessments can be useful to evaluate and monitor progress towards sustainable agriculture. This progress also requires identifying the main challenges and policies to address tem. The rest of the section presents a discussion of the main sustainability challenges in Chilean agriculture.

\section{Climate change adaptation and mitigation}

In 2018, the agricultural sector in Chile accounted for $10.5 \%$ of total GHG emissions $(6.7 \%$ of net emissions), down by 17\% since 1990 (MMA, 2021). The primary emission sources of the sector are enteric fermentation with $42.2 \%$, followed by $39.8 \%$ by agricultural land use, $12.7 \%$ by manure management, and $3.1 \%$ by urea application (MMA, 2018). For its part, the forestry sector (and land use) has net GHG captures representing -36\% of net emissions in 2018, mainly associated with the recovery of native forests (MMA, 2021; ODEPA, 2019). These captures have remained relatively stable since 1990 , rising by $6 \%$ since then, but are subject to the effects of forest fires. For example, in 2017, GHG captures went down approximately seven times from 2016 levels due to unusual heat that caused multiple forest fires in the country. Chile has committed to reducing its emissions by 2030 substantially and becoming carbon neutral by 2050; the NDC was updated, increasing the ambition of all its components (MMA, 2020).

On the other hand, the expected effects of climate change on agriculture in Chile remain highly uncertain but are mainly associated with changes in temperature and reduced precipitation, which implies a southward shift of agro-climatic zones (AGRIMED, 2008; MMA, 2020). According to Chile's Third National Communication to the United Nations Framework Convention on Climate Change (MMA, 2016), the agriculture and forestry sector is one of the most exposed to climate change in the country.

Although there are estimates of changes in climate (i.e., long-term averages or aggregations of climate variables), the most relevant effects on agriculture may be on changes in short-term climate phenomena, for which scarce but growing scientific research is available today. Long-term effects, although important, can be, in part, addressed through gradual autonomous adaptation measures, reducing or enhancing their impact. For this reason, models that evaluate long-term effects consider the fact that farmers will be able to adapt, for example, by changing their crops to ones better adapted to the new climate. In Chile, different studies have quantified the long-term effect of climate changes, finding moderate reductions in the GDP of the agriculture and forestry sector - in the range of 2 to $5 \%$ (ECLAC, 2009, 2012; ODEPA, 2010; Ponce et al., 2014; Melo \& Foster, 2021). These reductions could be primarily explained by reductions in water flows, especially in the agricultural areas of the center and north of the country. However, when looking at a particular region or commune, the effect may be much greater than when aggregated at the national level. Two aspects must be understood better to start building strategies to address agriculture's resilience to climate change: the process of autonomous adaptation and short-term climate effects.

\section{Pesticide pollution}

The use of pesticides can generate adverse effects on consumers' health due to residues in edible agricultural products, on agricultural workers due to lack of adequate protection, on neighboring communities that may receive pesticides through the wind or through surface or 
underground water on exposed ecosystems. The effects of this pollution can be acute or cumulative, causing intoxications and increasing the risk of diseases such as cancer or genetic alterations, neurological effects, and deformities in the fetus, among others (Zúñiga-Venegas et al., 2020). The Ministry of Health reported 824 acute pesticide poisonings in 2008, and in 2018 they reached 612. The reporting these events is required according to DS 88 of 2004 (Ministry of Health, 2019). A study in the Coquimbo region found high levels of pesticide exposure in the rural population near agricultural areas (Ramírez-Santana et al., 2018). Another study in the Maule region found high levels of pesticide contaminants in children's urine compared to the reference population in the USA (Muñoz- Quezada et al., 2019). In agricultural exports, like fresh fruits, there are incentives to reduce residues from certifications and monitoring in destination markets (Melo et al., 2014). Less clear is the situation for vegetable production, which in many cases is in the hands of small-scale farmers who may not have appropriate training or resources for adequate management of pesticides. For example, a study that evaluated the safety of leafy vegetables in the regions of Coquimbo, Valparaíso and Metropolitana found that in $42 \%$ of cases, the maximum residue limits established by the Ministry of Health based on the Codex Alimentarius were exceeded (Correa et al., 2017).

In addition to the effects on people's health, there are effects on ecosystems both inside and outside the farms. They can reduce biodiversity within farms, and also affect surrounding areas through wind drift, water contamination or by the transport by animals. There is considerable evidence of a decrease in plant, bird and insect biodiversity on agricultural land in Europe and North America (OECD, 2019).

\section{Loss of biodiversity}

Both the expansion of agricultural activity onto land with natural vegetation and the use of pesticides, fertilizers, and other agricultural practices can affect soil and water biodiversity. However, the homogenization of cultivated species is also a significant cause of biodiversity loss in agricultural lands. In the north-central zone of Chile, the cultivation of extensive agricultural lands with large-scale fruit trees has caused a significant reduction of native and endemic biodiversity in these territories isolated by the sea, the mountains and the desert. This is why there is an ongoing discussion regarding the best way to conserve biodiversity vis-a-vis maintaining productive capacity. This discussion has led to two main alternative strategies known as friendly agriculture versus land separation (Ginocchio et al., 2019) 4 . The former proposes increasing biodiversity within agricultural systems; instead the latter suggest maintaining intensive agriculture but putting aside areas for biodiversity conservation.

Another critical issue is the effect caused by invasive species that can cause significant economic losses to agriculture and forestry (Jacksic, \& Castro, 2021); in Chile the agencies responsible of this issue are part of the Ministry of Agriculture (Iriarte et al., 2005). Also a relevant is the afforestation with exotic species and its impact on native species (Heilmayr et al., 2020) and other conflicts with wildlife (Bonacic et al., 2016).

\section{Improving water management and reducing water conflicts}

Water conflicts in Chile arise from the quality or availability of water for society and the environ-

\footnotetext{
${ }^{4}$ Land separation consists of separating areas intended for the conservation of natural biodiversity (i.e. protected wild areas) from areas used for intensive agricultural production (Phalan et al., 2011).
} 
ment. Conflicts are due to quality problems in water used by agriculture, such as contamination from industrial liquid waste. However, they are also due to the effects of agriculture on water quality, affecting lakes or rivers. Agriculture also has conflicts over water availability, especially with owners of non-consumptive rights, such as hydroelectric plants (Donoso, 2018). Undoubtedly, water availability to cover the basic needs of communities near large-scale agricultural farms has been one of the most critical points of water conflicts faced by the agricultural sector in Chile. This type of conflict, which has shown to have potential consequences in international markets, is directly related to the projected trends of climate change and the increased frequency of droughts.

\section{Other environmental conflicts}

As mentioned above, part of the sector's environmental conflicts originates from pesticide contamination, loss of biodiversity, and water-related conflicts ${ }^{5}$. In this sense, specific contamination of water bodies by livestock and agro-industrial operations and diffuse contamination by fertilizers are sources of conflicts faced by the sector. However, there are other important sources of conflict, such as odor pollution. For example, the odor of pig farms affects the surrounding communities and other economic activities like tourism.

\section{Public policies and the sustainability of the agriculture and forestry sector}

The agriculture and forestry sector faces the critical challenge of meeting the growing demand for food, feed, and fiber while at the same time preserving ecosystems' health and providing a livelihood to agrarian societies in the context of climate change (Ray et al. 2013). Addressing these challenges requires a broader view of food systems that con- sider planetary limits and its effects globally and locally (Caron et al., 2018; Steffen et al., 2015). In this sense, diet composition is relevant not only for human health but also for the environment (Willett et al., 2019), and sustainable agriculture cannot be addressed independently.

Research has shown that adopting a greenrevolution type of technology cannot maintain the needed increase in productivity and that the increase is accompanied by environmental externalities (Lee et al., 2006). Transitioning towards sustainable agriculture will confront multiple agendas and varied interests of formal and informal institutions (the State, the private sector and civil society), and their interrelationships, obligations, processes, mechanisms and differences. Governance, investment, power, and politics converge at this interface and play their respective critical roles (Pretty et al., 2010).

To boost this transition investment funds should be directed towards the adoption of sustainable agriculture practices, research on agroecological systems, biologically diversified crops and whole-farm systems (DeLonge et al., 2016). The adoption of knowledge-intensive crop and livestock management practices like conservation tillage, integrated pest management and precision agriculture has been increasingly adopted by farmers seeking to increase efficiency in high-input, high-yield systems (Gollin et al., 2005). This approach, known as sustainable intensification, is based on the co-production of agricultural and natural capital outcomes shows promising advances worldwide but requires more substantial policy support (Pretty et al., 2018).

Policies at all levels influence the adoption and diffusion of sustainable agricultural systems. Exchange rate policies can affect the relative prices of exports and imports, tradable outputs

\footnotetext{
5 The Chilean National Institute for Human Rights presents a map of different conflicts including those related to environmental issues, see https://mapaconflictos.indh.cl/\#/.
} 
and inputs, and have substantial scope to influence technology adoption. Input subsidies for the use of fertilizers and other inputs have in the past created significant disincentives for the adoption of sustainable agriculture but have been eliminated in many countries as part of structural adjustment and sectoral policy changes. Labor policies may impact in both directions on the adoption of sustainable practices (Lee, 2005).

Investments in rural public education impact the educational outcomes of farm households, with accompanying impacts on management capacity. Increased investment in rural infrastructure, particularly in transportation, communications, and markets, is needed to improve the marketing and viability of diversified, high-value production opportunities, making these alternatives more economically attractive. Increased access to formal and informal credit sources will help farmers overcome short-term liquidity constraints. Securing land and water rights will make it easier for farm households to realize the long-term benefits of current-period investments and technology adoption and thus make these investments more attractive (Lee, 2005).

To make a transition towards sustainable agriculture economically viable, policies that help close the yield gap between biologically diversified and chemically intensive agricultural systems are needed (Ponisio et al., 2015). Also, production can be increased through more efficient use of arable land and by increasing yield growth rates. This can be achieved by disseminating best management practices and closing yield gaps in different production systems by implementing appropriate policies. A portion of the production shortfall could also be addressed through additional strategies. In particular, shifting to more plant-based diets and reducing food waste could reduce the expected growth in food demand and reduce the sector's impact on the environment (Ray et al., 2013).

Rockström et al., (2017) propose a new approach to achieve a paradigm shift towards sustainable intensification of agriculture. This approach integrates the dual and interdependent goals of using sustainable practices to meet growing human needs while contributing to the resilience and sustainability of landscapes, the biosphere, and the earth system. Both, in turn, are necessary to maintain the future viability of agriculture. This paradigm shift aims to reposition world agriculture from its current role as the main driver of global environmental change to become a key contributor to a global transition to a sustainable world within a secure operating space on the planet.

Achieving a sustainable food and agriculture sector requires better policy integration among sectoral ministries and the creation of partnerships and alliances beyond food and agriculture (FAO, 2018). An example of this vision is that put forward by the Nexus approach, which seeks to take an integrated look at policies associated with water, energy, food and the environment (Hoff, 2011; Ringler et al., 2013). This approach can also be combined with other approaches that focus on socioeconomic aspects, such as the livelihoods approach (Biggs et al., 2015) or that incorporate climate change (Cremades et al., 2019). This approach requires coordinated work between institutions from different sectors, which in developing countries can be especially problematic given the institutional weaknesses that exist in many cases (Melo et al., 2022).

Several countries have an explicit strategy for sustainable agriculture. Costa Rica has several agro-environmental policies and instruments to promote sustainable agriculture (FAO, 2016). Switzerland supports agricultural and rural development based on the enhancement of environmental services. India has participatory support for aquifer management and irrigation. China has a program that supports ecologically integrated demonstration villages. Sweden has a program to support organic agriculture (Pretty, 2008). Cuba has a national policy on alternative agriculture, where agroecological practices are used in 46-72\% of peasant farms (Altieri \& Nicholls, 2020). Many 
more agri-environmental policies are in place in several countries but few have a comprehensive support for sustainable agriculture.

In terms of sustainability initiatives, among many others, the Life Cycle Initiative, launched in 2002, stands out as a contribution to the promotion of sustainable production and consumption. Since then, several institutions have adopted this methodology (Olmos, 2017). A life cycle analysis (LCA) of agrifood products makes it possible to quantify resources used and outputs generated (e.g., energy, land, water, carbon) involved in the different production systems. This can be used to determine the environmental impact that the production of these foods can have and intervene in the processes where excessive use of resources is made to make them more efficient in environmental terms. This information can also inform consumers and promote a change in dietary patterns towards healthier products with less impact on the environment (Lusk \& McCluskey, 2018) or impose taxes or place trade restrictions.

Since the emergence of the concept of sustainable development and the use of this concept to the forestry and agriculture sector, the different countries of the world have made many agreements and commitments to make this sector increasingly environmentally friendly, socially fair and economically feasible. However, there is still a long way to implement policies and adopt sustainable agricultural practices by all actors involved in this sector along the value chain, including those who make and implement policies. Better policies should be context-specific and consider the region's agroclimatic, market, and institutional conditions (Lee et al., 2006).

In the following sections, we review current and recent public policies, private measures, and public-private efforts relevant to the sustainable development of Chile's agriculture and forestry sector. We first discuss the central public policies of environmental relevance that have been in place in Chile in the past five decades. Later, given the central role of climate change in the sustainability of the agriculture and forestry sector, we review policies related to this phenomenon in a separate section. We then present examples of public-private and private efforts to address the sector's sustainability.

\section{Public policies of environmental relevance in the Chilean agriculture and forestry sector}

The Chilean Ministry of Agriculture emphasizes that the design and implementation of comprehensive policies should aim to enhance sustainable agricultural and forestry production in the economic, social, and environmental areas, promoting strategies for adapting to climate change while maintaining the protection and value of the national phytosanitary and zoosanitary condition (MINAGRI, 2013, 2019). The growth and competitiveness of the rural economy must be enhanced through the application of policies and instruments that promote social development, especially considering the particularities of the most vulnerable groups in agriculture and the sustainable management of natural resources, which are increasingly subject to greater demand and competition among activities, as well as severe impacts from climate change.

We now present a brief review of the main programs from different government agencies that directly or indirectly affect the sustainability of the agriculture and forestry sector.

- Agro-environmental Sustainability of Agricultural Soils Incentive System: its objective is to recover and maintain the productive potential of degraded agricultural soils. It was created by Law 20.412 of 2010, but it originated with the Degraded Soils Recovery Program (1999-2009). It consists of non-reimbursable economic aid to co-financing those activities and practices used to recover degraded agricultural soils and maintain already recovered agricultural soils. ${ }^{6}$ The program's origin is compensation 
to farmers for the expected economic effects of a trade agreement with MERCOSUR. ${ }^{7}$ Even though it has some environmental aspects, probably to avoid trade regulations, its primary focus has been increasing and maintaining soil productivity. In 2009, a review panel recommended incorporating more explicitly the environmental objectives, leading to changes in the program. ${ }^{8}$ The program is managed by two institutions INDAP and SAG, each managing roughly half of the land treated by the program. The only impact evaluation of the program, done in 2016, found an increase in productivity for INDAP users, but no effects were found for SAG users, which have larger farms on average. ${ }^{9}$ No evaluation of the program has been done assessing its environmental impacts. A study using data from the 2016 evaluation found that program only plays a role in adopting practices used to recover degraded agricultural soils when farmers have a low intrinsic motivation (Bopp et al., 2019).

- Law 18,450 on irrigation promotion: this law was enacted in 1985 (CNR, 1985), and establishes that the State will subsidize up to $90 \%$ of the cost of study, construction and rehabilitation of irrigation or drainage works, and investments in equipment and mechanical irrigation elements, provided that they are executed to increase the irrigation area, improve water supply in deficiently irrigated areas, improve the efficiency of irrigation water application, habilitation and connection, whose projects are selected and approved in the manner established in this law. ${ }^{10}$ In addition, the Associative Irrigation Program has been implemented to co-finance investments in irrigation and drainage works to group of farmers. The Irrigation and Drainage Program was established with the objective of improving water management in the agricultural holdings of INDAP beneficiaries by providing incentives for irrigation or drainage projects and specialized consulting services, among others, which are necessary as a prerequisite or complement to the execution of irrigation or drainage works. On the other hand, the Individual Long-Term Credit for irrigation and/ or drainage linkage companies was created. Its purpose is to partially finance irrigation and/or drainage works that have obtained the Irrigation and Drainage Bonus Certificate granted by Law No. 18,450. The National Irrigation Commission (CNR) indicates that the potential irrigable area in Chile is 5.5 million hectares, of which 1.3 million (23.6\%) were under irrigation in 2013. The goal for 2020 was to reach an area of 1.7 million hectares. In its 2019 public account, the CNR reported that more than $82 \%$ of the resources were delivered to small farmers' projects, totaling a bonus of more than 74,000 million, which is a historical record and evidence of the country's commitment to irrigation as a response to Chile's water deficit ${ }^{11}$.

- INDAP's Local Development Program: the objective is to support rural families to strengthen their agriculture and forestry and associated activities, through the provision of technical advice and investment funds, enabling them to increase their income and improve their quality of life. This program is coordinated with public or private organizations, seeking to promote the development of small-scale agriculture in a comprehensive and sustainable manner (Fernández, 2013). The

\footnotetext{
https://www.odepa.gob.cl/temas-transversales/agricultura-sustentable/programa-de-suelos-sirsd-s

7 https://www.researchgate.net/publication/261644705_Instrumentos_de_Fomento_para_la_Forestacion_y_Recuperacion de Suelos en Chile

8 https://www.dipres.gob.cl/597/articles-141138_informe_final.pdf

9 https://bibliotecadigital.odepa.gob.cl/handle/20.500.12650/9099.

${ }_{10} \mathrm{https} / / / \mathrm{www} . \mathrm{cnr}$.gob.cl/agricultores/concursos-de-riego-y-drenaje/.

11 https://www.cnr.gob.cl/cuenta-publica-2019/.
} 
Program focuses on micro-producers, who are producers with low productive resources and assets, who develop agriculture in fragile ecosystems, aggravated by climate change, particularly the water deficit, limiting the productive potential of their production units. ${ }^{12}$

- Decree Law 701 for the Promotion of Forestry was enacted in 1974 and finalized in 2012. ${ }^{13}$ Since its implementation, more than $50 \%$ of the plantations were carried out under this instrument. However, from 1998 onwards, the incidence is drastically reduced, reaching less than $10 \%$ of the forested area in 2011 (Fernandez, 2013). This second phase, after 1998 , increased total funding and was geared towards small landowners and soil protection. ${ }^{14}$ Considering the additionality of the policy, Chavez et al. (forthcoming) find that only 35 to $40 \%$ of the planted area is attributable to the subsidy for the period 2008-2013. In that case, the economic profitability of the program is doubtful. Additionally, this policy has generated an increase in poverty in the localities where plantations have been carried out (Anríquez Nilson et al., 2020). And its environmental effects have been questioned due to a reduction in native forest, biodiversity and null contribution to carbon sequestration (Bopp et al., 2020; Heilmayr et al., 2020).

- Law 20.283: on the Recovery of Native Forest and Forestry Promotion as an efficient and effective tool for the sustainable development of the Chilean forestry sector. The objectives of this law are the protection, recovery, and improvement of native forests in order to ensure forest sustainability and environmental policy (CONAF, 2008). In addition, INDAP's long-term individual or company credit for the improvement of native forests is established with the objective of partially financing the costs of native forest management, which is given in association with the bonus granted by the State established in Law 20,283. In addition, the fund for the conservation, recovery and sustainable management of native forests was created to subsidize the execution of activities that favor the regeneration, recovery or protection of native forests; or silvicultural activities aimed at obtaining non-timber products; or silvicultural activities aimed at managing and recovering native forests for timber production purposes. In 2019, the payment for technical assistance was included as a bonus activity and the table of cost payment was increased (CONAF, 2019). There is currently an open call for applications to the fund ${ }^{15}$.

- Initiative on GIAHS (Important Systems of World Agricultural Heritage) and NIAHS (Important Systems of National Agricultural Heritage) sites. This initiative, which aims to rescue and enhance the current and future value of these territories' natural and cultural heritage, is promoted at the national level by the Office of Agricultural Studies and Policies (ODEPA). It is implemented at the regional and local levels by the Regional Ministerial Secretariats of Agriculture and the Institute for Agricultural Development (INDAP) to promote sustainability, add value to production, and promote inclusive development of the sector. In 2004, Chile joined FAO's work on the development of this initiative. Subsequently, between 2007 and 2009 the Ministry of Agriculture discussed the relevance of implementing this initiative in the national territory, and finally, in 2010 it began to be part of GIAHS global.

\footnotetext{
${ }^{12} \mathrm{https} / /$ www.indap.gob.cl/servicios-indap/nueva-plataforma-de-servicios\#programa-de-desarrollo-local-(prodesal).

${ }_{13} \mathrm{https} / /$ www.conaf.cl/nuestros-bosques/plantaciones-forestales/dl-701-y-sus-reglamentos/

${ }^{14} \mathrm{https}: / /$ www.dipres.gob.cl/597/articles-141195 informe final.pdf

${ }^{15} \mathrm{https}: / / w w w . c o n a f . c l / n u e s t r o s-b o s q u e s /$ bosque-nativo/fondo-de-conservacion-y-manejo-sustentable-del-bosque-nativo/.
} 
Intervention in the GIAHS sites promotes associativity, inclusion, participation of the different actors in the territory, the valorization of women's participation in the family group, and their important role in conserving and using agricultural biodiversity (Agüero, 2016; Espinoza et al., 2017).

- National Strategic Healthy Food Program Transforma Alimentos: ${ }^{16}$ This program was created to promote a new line of business in Chile to meet the growing global demand for this type of food. It is expected that by 2025, Chile will be positioned within the 10 countries that will lead healthy food in the world. These foods must be produced sustainably, have safety characteristics, provide additional benefits to their nutritional value, and reduce critical nutrients. Several entities, both public (Ministry of Agriculture, Ministry of Health, CORFO, etc.) and private (Chilealimentos, Hortifrut, Carozzi, etc.) contribute to this program, as well as academia (Universidad de Chile, INTA, Universidad Central) (Echeverría, 2016; Marchant, 2015).

- National Call for Innovation Projects of the Foundation for Agricultural Innovation, FIA ${ }^{17}$. Although this call has financed projects related to the sector's sustainability for several years, in its call for 2020, it has explicitly defined that innovative projects will be supported in the following three strategic challenges: 1 . Water Efficiency and Adaptation to Climate Change; 2. Development of innovative markets; and 3. Innovative processes. Likewise, in the calls made in 2015, 2016 and 2017, the aim was to support innovation for the development of sustainable agriculture that would contribute to the adaptation of the agriculture and forestry sector to climate change and thus strengthen the sector's resilience.
- Climate change policies and initiatives. In 2006, the country adopted the National Climate Change Strategy and two years later the Climate Change Action Plan was developed to evaluate the environmental, socio-economic and health impacts of this phenomenon. This information was used to define national and sectoral measures for adaptation to climate change. This plan determines that the agriculture and forestry sector must develop a sectoral adaptation and mitigation plan (Méndez \& Araya-Valenzuela, 2017). The Climate Change Action Plan focuses on the availability, research, innovation and optimization of water use, agro-climatic risks, integrated pest and disease control, genetic improvement and investment regarding information and adaptation to climate change, among other aspects (Muñoz et al., 2017). It should be noted that the social and economic dimensions of sustainability (its objective of improving the welfare of both producers and consumers) lag behind in these strategies, or at least are not directly addressed. In 2013, the Climate Change Adaptation Plan for the Agriculture and Forestry Sector was launched jointly by the Ministry of the Environment and the Ministry of Agriculture. This plan identifies the effects on different crops and highlights the effect on the hydrology of the Andes Mountains and the need for investment in infrastructure. The plan proposed 21 measures associated with the priorities and fields of action of the Ministry of Agriculture: improving the competitiveness of agriculture; promoting research and innovation; promoting economic, social and environmental sustainability; transparency and access to markets; and modernizing the Ministry of Agriculture and its services. Among the measures that promote sustainability are: Strengthening the current mechanisms of the Incentive

\footnotetext{
${ }^{16} \mathrm{https} / / /$ transformaalimentos.cl/.

$17 \mathrm{http}: / /$ www.fia.cl/convocatoria
} 
Systems Program for the Agro-environmental Sustainability of Agricultural Soils (formerly SIRSD); Developing permanent monitoring systems for changes in productivity potential; Developing a system of environmental sustainability indicators for agriculture; Developing new silvicultural methods to address climate change; Studying the water requirements of native and exotic forest species; Implementing rainwater harvesting systems for irrigation and drinking water. An analysis by the Comptroller General of the Republic audited the progress of 11 of these measures and found significant deficiencies in the management for their compliance. In October 2020, the design process for updating the plan was launched; this includes an effort to identify and evaluate regional adaptation measures and define a set of adaptation-progress indicators for the sector.

All these policies and initiatives contribute to promoting sustainable practices in the sector. Although some of them do not have sustainability as their main objective, they have a relevant impact. In addition, through access to credit, producers can improve their infrastructure, receive training in environmental and productive matters, obtain higher income and improve their quality of life, without affecting the natural resources in which they operate.

Private and public-private measures and initiatives

Between 2015 and 2018, the Sustainable Agriculture Work Plan was developed between the Clean Production Council (currently the Sustainability and Climate Change Agency, ASCC), INDAP, CORFO and ODEPA, which focused on public coordination to promote the incorporation of sustainability practices in agricultural producers, and thus improve their competitiveness. This plan sought to increase the number of companies that adhere and become certified in Clean Production Agreements (APL) and promote the dissemination and training in Clean Production and Sustainable Agriculture (ODEPA, 2018). In 2019, a new agreement was generated to give continuity to this plan, valid until June 2021.

Since 1999, when the APLs began operating, a total of 44 agreements have been signed by the agri-food sector, involving 4,793 member companies (ODEPA, 2019). The APLs are voluntary agreements between a business association representing a productive sector and the corresponding public agency. Its objectives are to commit producers to a set of goals and actions with a time frame. ${ }^{8}$ Some of the areas addressed in the APLs are: minimization and recycling measures; solid waste management; and a sustainable agriculture management plan for effluents and solid waste (Jiménez, 2007). This author states that one of the most fragile aspects of voluntary agreements is the lack of public participation of any kind. This is important to give legitimacy to the processes, get the rest of society involved, and cooperate to achieve greater sustainability of these systems.

Between 2015 and 2018, INDAP had the Sustainable Agriculture Program, which promoted sustainable practices in production systems and its participation in the Sustainable Agriculture Plan through technical assistance and training. These initiatives are complemented by the adaptations and innovations resulting from the National Research Program on Sustainable Agriculture and Environment of the National Agricultural Research Institute (INIA) (Acuña, 2018). Although INDAP continues to promote sectoral sustainability in its work, there is currently no structured program for this purpose.

In addition, there have been programs with a multisectoral focus, but which have also made

18 https://www.ascc.cl/pagina/apl 
it possible to incorporate environmental aspects into agricultural and forestry production. These programs are linked to the Chilean Development Corporation, $\mathrm{CORFO},{ }^{19}$ in particular to its REDES Management. Some of these programs are the Associative Network, the Markets Network and the Suppliers Network, and the Public Goods for Competitiveness calls for proposals. These programs do not focus on the agriculture and forestry sector or sustainability since CORFO's objective is to promote production. Nevertheless, it has been possible to address the sustainability challenges since it is understood that the sector's competitiveness depends on its sustainability.

Although it is not an agricultural policy, the recent National Rural Development Policy, coordinated by the Ministry of Agriculture, aims to improve the quality of life and increase opportunities for the rural population. ${ }^{20}$ This policy seeks to promote sustainable development in smaller settlements based on four areas: Social Welfare, Economic Opportunities, Environmental Sustainability, and Culture and Identity. The approval of this policy represents an important achievement in the coordination of sectoral policies and can guide the current process of political decentralization. However, it is less clear what could be its actual impact on the implementation or revision of policies and programs in future governments and how it can influence local regulations (Ossandón et al., 2020). This integrated and non-sectoral vision, which is finally beginning to permeate public policies, is essential to advancing sustainability.

One of the main drivers for the adoption of sustainable agricultural practices is the demands of the markets. Chile's agricultural development is based on an export model, so many subsectors and activities have been confronted with these requirements, which in some cases mean entering or not entering a given market. These requirements for Chilean products can come both from the destination countries and from intermediaries (for example, supermarket chains). On some occasions, industries have anticipated these market access requirements and have generated initiatives that allow product differentiation, thus improving the competitiveness of the sectors (Acuña, 2015; Muñoz et al., 2017).

Implementing policy instruments that promote agricultural sustainable practices depends on the country's specific political-institutional context. Chile has implemented subsidies for environmentally friendly agricultural practices (e.g., energy efficiency); innovation and knowledge management to enhance the value of traditional techniques; market access and food security; participatory organic certification standards and the creation of short circuits for the social construction of local markets (Le Coq et al., 2018; Sabourin et al., 2018).

Acuña (2015) details some of the private Chilean initiatives for sustainable agriculture and others developed by the Ministry of Agriculture. Below is a summary:

- Wine Sustainability Code: The Chilean wine industry has developed a series of projects to improve the sector's sustainability through the Wines of Chile Consortium. One of them is Climate Change and Winegrowing Zones to manage and monitor pesticide residues. Another project is "Biodiversity" which aims to integrate actions to conserve ecosystem services in their areas of development. These actions increase the resilience of these productive systems and the ecosystem that hosts them in the face of increasing human impact and climate change. As of 2015, 48 wineries in Chile were certified under this code, representing more than

\footnotetext{
www.corfo.cl

${ }^{2}$ https://www.odepa.gob.cl/wp-content/uploads/2020/08/DIARIO-OFICIAL-PNDR-DS19-2020.pdf
} 
$75 \%$ of the country's wine production volume (Wines of Chile, 2016).

- Policy and Guide to Good Sustainability Practices of the Chilean Exporters Association: ASOEX and the Foundation for Fruit Development (FDF) have been working on Good Agricultural Practices (GAP) for more than a decade. In recent years, they have expanded their work towards sustainability, always starting from the basis of GAP. In 2013, a Sustainability Program for the Chilean fruit industry was proposed, which focuses on safety as a fundamental factor for the sector's sustainability, although it considers the three pillars of sustainability (ChileGAP, 2013).

- Environmental Sustainability Program at Nestlé dairy farms: Nestlé has a corporate sustainability policy called the Shared Value Policy, which provides sustainability guidelines for the company's various operations worldwide. Since 2011 it has been developing an Environmental Sustainability Program in dairy farms. They have a payment system, which translates into a higher price per liter of milk for those dairy farmers who meet specific sustainability requirements. The Sustainability Manual considers five components: environmental protection, low carbon dairy, environmental services, animal welfare, and protection of human health (Nestlé Chile, 2018).

- Sustainable Agriculture Protocol: the purpose of this protocol is to provide a common language and a basic understanding of sustainability in the agricultural sector and recommendations for good practices to be implemented by farmers. This protocol provides an overview of what is meant by sustainable agriculture in Chile. Ten principles of sustainable agriculture are identified that provide a general and comprehensive framework for sustainability in the sector, including environmental and social issues: Monitoring and use of water resources; Respect for human rights and labor conditions; Waste management; Management and application of agrochemicals; Safety management and traceability; Relationship with local communities; Management of biodiversity and ecosystem services; Energy management; Soil management and conservation; and Ensuring animal health and welfare (ODEPA, 2016).

- Sustainability Working Group of the Agri-Food Export Council: is a public-private instance to promote food exports. In particular, the sustainability group has developed a work plan to optimize the sector's sustainability practices in order to make it more competitive in foreign markets and position Chilean food exports as a sector committed to sustainable development.

- The national pork sector has quality assurance programs, biosafety, and traceability systems Olmos (2017). This association of swine producers has defined a national strategy for 2020 , based on implementing best practices to achieve healthy, clean, quality production. The sustainability approach defined by the sector identifies challenges concerning the care of the environment, workers, and the community.

This section has shown the efforts made in Chile to improve the sustainability of the agriculture and forestry sector. Several initiatives and policies have been developed by both the State and the private sector. Given the vulnerability of this sector to the effects of climate change and its importance for food and human health and its high negative impact on the environment, it is vitally important to adopt policies that promote sustainable practices.

The current pandemic affecting the world and Chile, in particular, have demonstrated the urgent need to rethink and direct policies to promote a sustainable agriculture and forestry sector based on all the dimensions of sustainability. A better articulation between the different actors involved in the agriculture and forestry sector, 
with a contribution of knowledge from all parties and the lessons learned from good experiences nationally and internationally, can transition to more resilient and sustainable agrifood systems.

\section{Policy Recommendations}

Most of the sector's current policies originated to promote the growth of the activity. Many of these policies and programs began by including support for medium to large companies or farmers, but as the sector and country developed, they have increasingly focused on smaller-scale farms. Most of these policies also did not include environmental considerations in their design, but some have slowly incorporated them. However, the first step to advancing the sustainability of the sector's policies is to evaluate current policies' economic, social and environmental effects. As presented in this document, some programs have undergone this type of analysis. Also, the Directorate of Budget (DIPRES) promotes expost reviews and impact evaluations of programs and policies, although usually centered around the main objectives and not secondary ones, or unintended consequences.

In addition, more resources should be allocated to research on the medium- and long-term intraand extra-industry consequences of different agricultural practices. Moreover, innovation in practices, technologies or systems that can address sustainability problems should be promoted, and their adequate transfer and adoption by farmers should be ensured. Along with increasing research and innovation in sustainability, priority should be given to developing and monitoring agricultural sustainability indicators. Today there is very little information available to construct agricultural sustainability indicators. For example, the OECD uses the presence of birds on agricultural land as an indicator of biodiversity, an indicator for which there is no information in Chile (OECD, 2019). Finally, it is essential to ensure the continuity of the established policies; only in this way will it be possible to make substantive progress towards sectoral sustainability.

One of the areas where the least information is available is land use. This information is key to characterizing and monitoring different environmental indicators' evolution in the agriculture and forestry sector. Today, technology would allow remote measurement of changes in land use with a greater frequency than that provided by the National Agricultural Census and other instruments. Why has this type of survey not been systematically implemented, given its lower cost? The lack of these periodic measurements presents a vacuum in characterizing what is happening with key environmental variables. It makes it difficult to evaluate the impacts of policies that may affect land use and the effects of climate change.

Another critical aspect for which there is still very little information in the country is the amount of water withdrawn from natural watercourses and aquifers. Although there are specific examples where this is measured, there is still a long way to monitor the consumptive use of inland waters. An essential but incipient step is the DS 53 of the DGA (MOP, 2020), which requires installing flow meters and reporting abstractions.

One of the main challenges of the sector is the use of pesticides. Again, there is limited research and monitoring in this area, which should undoubtedly be strengthened. There is also a critical absence of fundamental indicators such as the apparent use of pesticides by type. These indicators should be developed and have a geographical location and a more detailed specification according to the level of toxicity. Likewise, there should be a more detailed follow-up of poisoning cases to provide information to reduce their occurrence, as well as long-term follow-up studies of the consequences of their use.

The Chilean Ministry of Agriculture is currently responsible for conserving a large part 
of the native continental flora and fauna and controlling invasive species, mainly through SAG and CONAF. According to a recent pronouncement of the General Comptroller of the Republic, the role of CONAF since 2008 in the illegal approval of management plans to replace native forest with agricultural activity is of particular concern. ${ }^{21}$

If we look at agricultural policies in developed countries, we can see that the sector has important protection or support for some activities or segments of farmers in many cases. Moreover, although these supports are in some cases being reduced, they have had critical environmental consequences (OECD, 2019). Today, most OECD countries have introduced payment for environmental services schemes. These schemes often combine social objectives with the achievement of environmental goals. Although existing evaluations are not very auspicious regarding the impact of these instruments due to additionality problems, there is no doubt that this alternative is better than implementing support schemes that may incentivize production or the use of inputs or production factors that cause environmental degradation.

\section{Conclusions}

Sustainable agriculture can be understood as a type of agriculture that is intensive in knowledge about nature's processes and consumers and stakeholder preferences. Within the Sustainable Development Goals framework, there is global recognition of the importance of integrating economic, social and environmental aspects to achieve a sustainable agriculture and forestry sector. Although there is no consensus on the concept of sustainability, there is a growing concern about making agri-food systems more environmentally friendly, resilient to shocks of any kind, fairer, able to produce more affordable food, and increasing society's welfare as a whole. There have been several initiatives aiming to address these concerns at different scales ( international, national, local, networks, among others) and they should continue to increase in number and cover all products and actors.

The export oriented development of Chilean agriculture and forestry sector has brought bothe challenges and opportunities. To continue providing weelbeing to society the sector needs to address local and global societal demands. There are many challenges in getting the agriculture and forestry sector to adopt these changes, but if all the actors involved in the sector understand the benefits, the task will be easier. These changes will also require governments, the private sector, civil society and academia to collectively create the necessary mechanisms. The Chilean Ministry of Agriculture and its services should integrate sustainability in all its policies first by reviewing existing ones and second by proposing new ones that address the main challenges faced by the agriculture and forestry sector.

\footnotetext{
${ }^{21}$ https://www.contraloria.cl/pdfbuscador/dictamenes/006271N20/html
} 


\title{
Resumen
}

\begin{abstract}
O. Melo, N. Báez Quiñones, y D. Acuña. 2021. Hacia una agricultura sustentable en Chile, reflexiones sobre el rol de las políticas públicas. Int. J. Agric. Nat. Resour. 186-209. Dada la creciente demanda de productos agrícolas y la degradación ambiental que generan las actuales prácticas agrícolas, existe una necesidad urgente de cambiar la actividad. La agricultura sostenible surge como una alternativa atractiva para mitigar los efectos adversos de la actividad sobre el medio ambiente, aumentar su resiliencia al cambio global y aumentar la calidad de vida de la población actual sin sacrificar la de las generaciones futuras. Sin embargo, la identificación de políticas efectivas que puedan alcanzar estos objetivos sigue siendo difícil. En Chile, este sector ha sido uno de los impulsores del crecimiento y la reducción de la pobreza, pero aún enfrenta muchos desafíos ambientales y sociales, y existe una creciente demanda pública por lograr la sustentabilidad desde una perspectiva económica, ambiental y social. Las instituciones públicas y privadas han realizado esfuerzos relevantes para aumentar la sostenibilidad de la agricultura chilena. Sin embargo, la necesidad de transitar hacia una agricultura sostenible aún no es reconocida por todos los actores. En este artículo se revisan los retos y políticas actuales para lograr una agricultura más sostenible en Chile
\end{abstract}

Palabras clave: Sector forestal y ganadero, sostenibilidad.

\section{References}

Acuña, D. (2015). Sustainable agriculture: background and initiatives. Oficina De Estudios $Y$ Politicas Agrarias, 1987, 1-7. http://www.odepa.cl/wp- content/files_mf/1435948962Agricult urasostenible2015.pdf

Acuña, D. (2018). Sustainable Development Goals and the Chilean agricultural sector. www.odepa. gob.cl

Agosin, M.R., \& Bravo-Ortega, C. (2012). The Emergence of New Successful Export Activities in Latin America: The Case of Chile. SSRN Electronic Journal. https://doi.org/10.2139/ ssrn. 1807608

AGRIMED. (2008). Impactos productivos en el sector silvoagropecuario de Chile frente a escenarios de cambio climático. In Análisis de vulnerabilidad del sector silvoagropecuario, recursos hídricos y edáficos de Chile frente a escenarios de cambio climático. Centro de Agricultura y Medio Ambiente.

Agüero, T. (2016). GIAHS sites: rescue and valorization of the agricultural and cultural heritage of a territory.
Altieri, M.A., \& Nicholls, C.I. (2020). Agroecology and the reconstruction of a post- COVID-19 agriculture. Journal of Peasant Studies, 47(5), 881-898. https://doi.org/10.1080/03066150.2020.1782891

Amekawa, Y. (2011). Agroecology and sustainable livelihoods: Towards an integrated approach to rural development. Journal of Sustainable Agriculture, 35(2), 118-162. https://doi.org/10.1080/ 10440046.2011.539124

Anríquez, G., \& Melo, O. (2018). The Socio-Economic Context of Chilean Water Consumption and Water Markets Growth: 1985-2015 (pp. 53-63). Springer, Cham. https://doi.org/10.1007/978-3319-76702-4_4

Anríquez Nilson, G., Toledo Roman, G., \& Arriagada Cisternas, R. (2020). Hidden welfare effects of tree plantations. Environment and Development Economics, 26(2), 151-168. https://doi. org/10.1017/S1355770X20000303.

Antle, J.M., \& Diagana, B. (2003). Creating Incentives For The Adoption Of Sustainable Agricultural Practices In Developing Countries: The Role Of Soil Carbon Sequestration. Amer. J. Agr. Econ. , 85(5), 1178-1184. https://doi.org/10.1146/annurev.immunol.22.012703.104549. 
Barham, B., Clark, M., Katz, E., \& Schurman, R. (1992). Nontraditional agricultural exports in Latin America. Latin American Research Review, 27(2), 43-82. https://doi.org/10.2307/2503749

Baylis, K., Peplow, S., Rausser, G., \& Simon, L. (2008). Agri-environmental policies in the EU and United States: A comparison. Ecological Economics, 65(4), 753-764. https://doi. org/10.1016/j.ecolecon.2007.07.034

Biggs, E.M., Bruce, E., Boruff, B., Duncan, J.M.A., Horsley, J., Pauli, N., McNeill, K., Neef, A., Van Ogtrop, F., Curnow, J., Haworth, B., Duce, S., \& Imanari, Y. (2015). Sustainable development and the water-energy-food nexus: A perspective on livelihoods. Environmental Science \& Policy, 54, 389-397. https://doi.org/10.1016/J.ENVSCI.2015.08.002.

Bonacic, C. Amaya-Espinel, J.D., Ibarra, J.T. (2016). Human Wildlife conflicts an overview of cases and lessons from the andean región. In: A. Alonso Aguirre, Raman Sukumar eds. Tropical Conservation: Perspectives on Local and Global Priorities. Oxford University Press, 400 pp.

Bopp, C., Engler, A., Poortvliet, P.M., \& Jara-Rojas, R. (2019). The role of farmers' intrinsic motivation in the effectiveness of policy incentives to promote sustainable agricultural practices. Journal of Environmental Management, 244, 320-327. https://doi.org/10.1016/J.JENVMAN.2019.04.107

Bopp, C., Engler, A., Jara-Rojas, R., \& Arriagada, R. (2020). Are forest plantation subsidies affecting land use change and off-farm income? A farmlevel analysis of Chilean small forest landowners. Land Use Policy, 91, 104308. https://doi. org/10.1016/j.landusepol.2019.104308

Bravo-Ortega, C., \& D. Lederman. 2005. "Agriculture and National Welfare Around the World: Causality and International Heterogeneity Since 1960.” Policy Research Working Paper Series 3499. The World Bank.

Brodt, S., Six, J., Feenstra, G., Ingels, C., \& Campbell, D. (2011). Sustainable agriculture. Nature Education Knowledge, 3(10), 1-11. https://doi. org/10.1007/978-94-007-0394-0.

Brundtland, H. (1987). Our common future. In $O x$ - ford (for the World Commission on Environment and Development). Oxford University Press.

Central Bank of Chile. (2020). Foreign trade indicators. Tercer trimestre de 2020. https://www. bcentral.cl/documents/33528/133362/ICE_tercer_trimestre_2020.pdf/122 fdd2f-9231-3f1efla6-8c73d4169d16?t=1605904144927

Caron, P., Loma-Osorio, G. F. y de, Nabarro, D., Hainzelin, E., Guillou, M., Andersen, I., Arnold, T., Astralaga, M., Beukeboom, M., Bickersteth, S., Bwalya, M., Caballero, P., Campbell, B. M., Divine, N., Fan, S., Frick, M., Friis, A., Gallagher, M., Halkin, J.-P., ... Verburg, G. (2018). Food systems for sustainable development: proposals for a profound four-part transformation. Agronomy for Sustainable Development, 38(4), 1-12. https://doi.org/10.1007/S13593-018-0519-1

Chavez, F., Arriaga, R., Foster, W., \& Melo, O. The Impact of the Forest Subsidy Program: An ex post assessment of Chilean plantations.

ChileGAP. (2013). Good Practices for the Sustainability of the Chilean Fruit Industry. https///:asoex.cl/images/images/documents/ guiasBPA/guia_sus_eng_217.pdf.

CNR. (1985). Law No. 18,450 on Promotion of Private Investment in Irrigation and Drainage Works.

CONAF. (2008). Law 20.283 on native forest recovery and forestry promotion and Regulations.

CONAF. (2019). Participatory Public Accounts. Gestión 2019. In Education and dissemination (p. 86). National Forestry Corporation, Ministry of Agriculture. http://www.conaf.cl/incendiosforestales/prevencion/educacion-y-difusion/.

Correa, A., Quiroz, C., Sepúlveda, P., Salas, C., Moyano, S., Elgueta, S., \& Astudillo, C. (2017). Strengthening safety in leafy vegetables. Phytosanitary management strategies in lettuce, chard and spinach (INIA Bulletin No348; Instituto de Investigaciones Agropecuarias, Chile).

Cremades, R., Mitter, H., Tudose, N.C., SanchezPlaza, A., Graves, A., Broekman, A., Bender, S., Giupponi, C., Koundouri, P., Bahri, M., Cheval, S., Cortekar, J., Moreno, Y., Melo, O., Karner, K., Ungurean, C., Davidescu, S.O., Kropf, B., Brouwer, F., \& Marin, M. (2019). Ten principles 
to integrate the water-energy-land nexus with climate services for co-producing local and regional integrated assessments. Science of The Total Environment, 693, 133662. https://doi. org/10.1016/j.scitotenv.2019.133662.

de Ferranti, D., Perry, G.E., \& Foster, W. (2005). Beyond the City: The Rural Contribution to Development. World Bank Latin American and Caribbean Studies.

DeLonge, M.S., Miles, A., \& Carlisle, L. (2016). Investing in the transition to sustainable agriculture. Environmental Science and Policy, 55, 266-273. https://doi.org/10.1016/j.envsci.2015.09.013

Donoso, G. (2018). Water governance in Chile: Challenges and proposals for improvement ( $\mathrm{p}$. 46). Department of Agricultural Economics, Pontificia Universidad Católica de Chile. https:// cambioglobal.uc.cl/images/noticias/015_3 Gobernanza Agua Donoso.pdf.

Echeñique, J., \& Romero, L. (2009). Evolution of Family Farming in Chile in the Period 19972007. FAO Chile.

Echeverría, H. (2016). Agriculture And Sustainability In Chile: Achievements And Challenges. Vi Innovagro Zacatecas 2016 Meeting.

ECLAC. (2009). The Economics Of Climate Change In Chile Synthesis (J. Samaniego, C. J. De Miguel, L. M. Galindo, J. J. Gómez, K. Martínez, \& O. Cetrángolo (eds.)). ECLAC.

ECLAC. (2012). The Economics of Climate Change in Chile. In United Nations. ECLAC.

Espinoza, J., Agüero, T., \& Apey, A. (2017). Environmental considerations for a competitive and sustainable agriculture to 2030. In A. A. Guzmán, D. B. Pedraza, \& T. R. Sius (Eds.), Agricultura Chilena Reflexiones y Desafios al 2030 (First Ed, pp. 117- 129).

FAO. (2014). Agriculture, Forestry and Other Land Use Emissions by Sources and Removals by Sinks (ESS/14-02.; FAO Statistics Division Working Paper Series).

FAO. (2016). Experiences of implementation of public policies that promote sustainable agriculture in Costa Rica: Identification, systematization and analysis. Organización de Las Naciones Unidas Para La Alimentación y La
Agricultura - FAO, 1-155. http://www.fao. org/3/a-i5662s.pdf

FAO. (2018). Transforming food and agriculture to achieve the SDGs. In Food and Agriculture Organization of the United Nations. http://www. fao.org/3/I9900ES/i9900es.PDF

Fernández, M.P. (2013). Agri-Environmental Policies In Chile. Proyecto GCP/RLA/195/BRA "Fortalecimiento de Políticas agro-ambientales en países de América Latina y el Caribe a través de Diálogo e Intercambio de Experiencias Nacionales"

Filson, G.C. (1996). Demographic and farm characteristic differences in ontario farmers' views about sustainability policies. Journal of Agricultural and Environmental Ethics, 9(2), 165-180. https://doi.org/10.1007/BF03055300.

Foster, W., \& Valdés, A. (2015). Measuring the Size of the Renewable Resource Sector: the Case of Chile. World Food Policy, 2(1), 19-35. https:// doi.org/10.18278/wfp.2.1.2

Gastó, J., Vera, L., Vieli, L., \& Montalba, R. (2009). Sustainable Agriculture: Unifying Concepts. In Cien. Inv. Agr (Vol. 36, Issue 1).

Ginocchio, R., Melo, O., Pliscoff, P., Camus, P., \& Arellano, E.C. (2019). Conflict between agricultural intensification and biodiversity conservation in Chile: alternatives for reconciliation. Center for Public Policy, 15(118), 24p.

Gökkür, S., \& Sinav, E. (2020). Sustainable Agriculture and New Food Marketing Management System. Eurasian Journal of Agricultural Research, 4(1), 45-55.

Gollin, D., Morris, M., \& Byerlee, D. (2005). Technology adoption in intensive post-green revolution systems. American Journal of Agricultural Economics, 87(5), 1310-1316. https://doi. org/10.1111/j.1467-8276.2005.00824.x

Heilmayr, R., Echeverría, C., \& Lambin, E.F. (2020). Impacts of Chilean forest subsidies on forest cover, carbon and biodiversity. Nature Sustainability, 3(9), 701-709. https://doi.org/10.1038/ s41893-020-0547-0

Hoff, H. (2011). Understanding the Nexus. Background Paper for the Bonn 2011 Conference: The Water, Energy and Food Security Nexus. In Stockholm Environment Institute. 
Iriarte, A.J., Lobos, G.A., \& Jaksic, F.M. (2005). Invasive vertebrate species in Chile and their control and monitoring by governmental agencies. Revista Chilena de Historia Natural, 78(1), 143-151. https://doi.org/10.4067/S0716078X2005000100010

Jaksic, F.M., \& Castro, S.A. (2021). Impacts on Human Health, Economy and Biodiversity. Biological Invasions in the South American Anthropocene, 111-133. https://doi.org/10.1007/978-3030-56379-0 6.

Jiménez, O. (2007). Voluntary agreements in environmental policy: an empirical evaluation for the Chilean case. Journal of Cleaner Production, 15(7), 620-637. https://doi.org/10.1016/j. jclepro.2005.11.025

Khanna, M., Swinton, S.M., \& Messer, K.D. (2018). Sustaining our natural resources in the face of increasing societal demands on agriculture: Directions for future research. Applied Economic Perspectives and Policy, 40(1), 38-59. https:// doi.org/10.1093/aepp/ppx055.

Lebdioui, A. (2019). Chile's Export Diversification since 1960: A Free Market Miracle or Mirage? Development and Change, 50(6), 1624-1663. https://doi.org/10.1111/dech.12545

Le Coq, J., Patrouilleau, M.M., Sabourin, E., \& Niederle, P.A. (2018). Public policies that promote agroecology and organic agriculture in Latin America. III Conferência Interna- Cional de Agricultura e Alimentação Em Uma Sociedade Urbanizada. https://hal.archives-ouvertes.fr/hal-02794344

Lee, D.R. (2005). Agricultural Sustainability And Technology Adoption:Issues And Policies For Developing Countries. Amer. J. Agr. Econ., 87(5), 1325-1334.

Lee, D.R., Barrett, C.B., \& McPeak, J.G. (2006). Policy, technology, and management strategies for achieving sustainable agricultural intensification. Agricultural Economics, 34(2), 123-127. https:// doi.org/10.1111/j.1574-0864.2006.00112.x.

Lusk, J.L., \& McCluskey, J. (2018). Understanding the impacts of food consumer choice and food policy outcomes. Applied Economic Perspectives and Policy, 40(1), 5-21. https://doi.org/10.1093/ aepp/ppx054.
Marchant, R. (2015). National Strategic Program "Alimentos Saludables" New approach for the national food industry.

Meller, P., \& Saéz, R.E. (1995). Auge Exportador Chileno: Lecciones y Desafios. Dolmen Ediciones.

Melo, O., Engler, A., Nahuehual, L., Cofre, G., \& Barrena, J. (2014). Do Sanitary, phytosanitary, and quality-related standards affect international trade? Evidence from Chilean fruit exports. World Development, 54(2009), 350-359. https:// doi.org/10.1016/j.worlddev.2013.10.005

Melo, O., \& Foster, W. (2021). Agricultural and Forestry Land and Labor Use under Long- Term Climate Change in Chile. Atmosphere, 12(3), 305. https://doi.org/10.3390/atmos 12030305.

Melo, O., Naranjo, L., Rey, D., Salmoral, G., \& Viteri-Salazar, O., \& Zegarra, E. (2022). Agricultural development in the Andean countries and the nexus. In F. Brouwer (Ed.), Handbook on the Water-Energy-Food Nexus. In press.

Méndez, C., \& Araya-Valenzuela, R. (2017). Climate change and production of essential annual crops. A look from food security in Chile. Politica y Estrategia, 129, 157-187.

MINAGRI. (2013). Plan for Adaptation to Climate Change in the Forestry and Livestock Sector. http://www.mma.gob.cl/1304/articles- 55879 InstrumentoFinalCC Silvoagropecuario.pdf

MINAGRI. (2019). Cuenta Pública Participativa MINAGRI 2019 (p. 138). Ministry of Agriculture, Government of Chile. https://cuentapublica. minagri.gob.cl/.

Ministry of Health. (2019). National surveillance of acute pesticide poisoning - REVEP (p. 28). Department of Epidemiology Health Planning Division Subsecretaría de Salud Pública. https:// www.senado.cl/appsenado/index.php? $\mathrm{mo}=$ trami tacion $\&$ ac $=$ getDocto $\&$ iddocto $=5780 \&$ tipodoc $=$ docto comision

MMA. (2016). Third National Communication of Chile to the United Nations Framework Convention on Climate Change (p. 504). Gef and UNDP.

MMA. (2018). Chile's third biennial update report on Climate Change (p. 397). Gef and UNDP.

MMA. (2020). Chile's Nationally Determined Con- 
tribution (NDC) (p. 96). Ministry of Environment, Government of Chile.

MMA. (2021). Cuarta Comunicación Nacional de Chile a la Convención Marco de las Naciones Unidas (p. 537). Gef and UNDP.Santiago.

MOP. (2020). Reglamento de Monitoreo de Extracciones Efectivas de Aguas Superficiales.

Muñoz-Quezada, M.T., Lucero, B., Bradman, A., Steenland, K., Zúñiga, L., Calafat, A.M., Ospina, M., Iglesias, V., Muñoz, M.P., Buralli, R.J., Fredes, C., \& Gutiérrez, J.P. (2019). An educational intervention on the risk perception of pesticides exposure and organophosphate metabolites urinary concentrations in rural school children in Maule Region, Chile. Environmental Research, 176, 108554. https://doi.org/10.1016/j. envres.2019.108554.

Muñoz, C., Mattar, C., Neira, R., Mora, M., Espinoza, J., Seguel, Ó., Salazar, O., Fuster, R., Lizana, L.A., Cofré, C., Pinheiro, A., \& Rodríguez, L. (2017). Sustainable Agriculture and Healthy Food in Chile. In Challenges And Opportunities For Food And Nutrition Security In The Americas: The View of The Academies Of Sciences (pp. 191-211).

Negoita, M., \& Block, F. (2012). Networks and Public Policies in the Global South: The Chilean Case and the Future of the Developmental Network State. Studies in Comparative International Development, 47(1), 1-22. https://doi. org/10.1007/s12116-012-9097-4

Nestlé Chile. (2018). Nestlé Chile Sustainability Report 2018.

ODEPA. (2010). Estimación del Impacto Socioeconómico del Cambio Climático en el Sector Silvoagropecuario de Chile (p. 154). Oficina de Estudios y Políticas Agrarias, Santiago de Chile.

ODEPA. (2016). Sustainable Agriculture Protocol. https://www.odepa.gob.cl/publicaciones/articulos/protocolo-de-agricultura- sustentable.

ODEPA. (2018). Sustainable agriculture plan. 1-5. www.odepa.gob.cl/wp- content/ uploads/2017/12/2-Plan-de-Agricultura-Sustentable.pdf

ODEPA. (2019). Panorama de la Agricultura Chilena. www.odepa.gob.cl
OECD. (2016). Chile must adopt measures to curb pressures on the environment.

OECD. (2019). Trends and Drivers of Agri-environmental Performance in OECD Countries.OECD. https://doi.org/10.1787/b59b1142-en

Olmos, X. (2017). Environmental sustainability of agri-food exports: The cases of Chile, Colombia, Ecuador and Uruguay. Comisión Económica para América Latina y el Caribe (CEPAL)

Ossandón, A.O., Alba, D.M., Otárola, D.I., \& Gajardo, K.M. (2020). Analysis Of The Perspective Of Integrating The National Rural Development Policy: Into Communal Development Plans In Chile. Revista Urbano, 42, 66-79.

Phalan, B., Onial, M., Balmford, A., \& Green, R.E. (2011). Reconciling food production and biodiversity conservation: Land sharing and land sparing compared. Science, 333, 1289-1291. https:// doi.org/10.1126/science.1208742.

Ponce, R., Blanco, M., \& Giupponi, C. (2014). The economic impacts of climate change on the Chilean agricultural sector. A non-linear agricultural supply model. Chilean Journal of Agricultural Research, 74(4), 404-412. https://doi. org/10.4067/S0718-58392014000400005

Ponisio, L.C., M'gonigle, L.K., Mace, K.C., Palomino, J., Valpine, P. De, \& Kremen, C. (2015). Diversification practices reduce organic to conventional yield gap. Proceedings of the Royal Society B: Biological Sciences, 282(1799). https:// doi.org/10.1098/rspb.2014.1396

Pretty, J. (2008). Agricultural Sustainability: Concepts, Principles and Evidence. Philosophical Transactions: Biological Sciences, 363(1491), 447-465. http://www.jstor.org.pucdechile.idm. oclc.org/stable/20208443

Pretty, J., Benton, T.G., Bharucha, Z.P., Dicks, L.V., Flora, C.B., Godfray, H.C.J., Goulson, D., Hartley, S., Lampkin, N., Morris, C., Pierzynski, G., Prasad, P.V.V., Reganold, J., Rockström, J., Smith, P., Thorne, P., \& Wratten, S. (2018). Global assessment of agricultural system redesign for sustainable intensification. Nature Sustainability, 1(8), 441446. https://doi.org/10.1038/s41893-018-0114-0

Pretty, J., Sutherland, W.J., Ashby, J., Auburn, J., Baulcombe, D., Bell, M., Bentley, J., Bicker- 
steth, S., Brown, K., Burke, J., Campbell, H., Chen, K., Crowley, E., Crute, I., Dobbelaere, D., Edwards-Jones, G., Funes-Monzote, F., Charles, H., Godfray, J., ... Pilgrim, S. (2010). The top 100 questions of importance to the future of global agriculture. International Journal Of Agricultural Sustainability, 8(4), 219-236. https://doi. org/10.3763/ijas.2010.0534

Ramírez-Santana, M., Farías-Gómez, C., ZúñigaVenegas, L., Sandoval, R., Roeleveld, N., Van der Velden, K., Scheepers, P.T.J., \& Pancetti, F. (2018). Biomonitoring of blood cholinesterases and acylpeptide hydrolase activities in rural inhabitants exposed to pesticides in the Coquimbo Region of Chile. PLOS ONE, 13(5), e0196084. https://doi.org/10.1371/journal.pone.0196084.

Ray, D.K., Mueller, N.D., West, P.C., \& Foley, J.A. (2013). Yield Trends Are Insufficient to Double Global Crop Production by 2050. PLoS ONE, $8(6)$. https://doi.org/10.1371/journal. pone. 0066428 .

Ringler, C., Bhaduri, A., \& Lawford, R. (2013). The nexus across water, energy, land and food (WELF): Potential for improved resource use efficiency? In Current Opinion in Environmental Sustainability (Vol. 5, Issue 6, pp. 617-624). Elsevier. https://doi.org/10.1016/j.cosust.2013.11.002

Rockström, J., Williams, J., Daily, G., Noble, A., Matthews, N., Gordon, L., Wetterstrand, H., DeClerck, F., Shah, M., Steduto, P., de Fraiture, C., Hatibu, N., Unver, O., Bird, J., Sibanda, L., \& Smith, J. (2017). Sustainable intensification of agriculture for human prosperity and global sustainability. Ambio, 46(1), 4-17. https://doi. org/10.1007/s13280-016-0793-6.

Sabourin, E., Le Coq, J.-F., Fréguin-Gresh, S., Marzin, J., Bonin, M., Patrouilleau, M.M., Vázquez, L.L., \& Niederle, P. (2018). What public policies promote agroecology in Latin America and the Caribbean? Perspective: The Policy Brief From
CIRAD, 45, 1-4. https://doi.org/10.19182/agritrop/00019.

Steffen, W., Richardson, K., Rockström, J., Cornell, S.E., Fetzer, I., Bennett, E.M., Biggs, R., Carpenter, S.R., De Vries, W., De Wit, C.A., Folke, C., Gerten, D., Heinke, J., Mace, G.M., Persson, L.M., Ramanathan, V., Reyers, B., \& Sörlin, S. (2015). Planetary boundaries: Guiding human development on a changing planet. Science, 347(6223). https://doi.org/10.1126/SCIENCE. 1259855

Valdés, A. (1994). Agricultural Reforms In Chile And New Zealand: A Review. Journal of Agricultural Economics, 45(2), 189-201. https://doi. org/10.1111/j.1477-9552.1994.tb00393.x

Valdés, A., \& Foster, W. (2010). Reflections on the Role of Agriculture in Pro-Poor Growth. World Development, 38(10), 1362-1374. https://doi. org/10.1016/j.worlddev.2010.06.003

Velten, S., Leventon, J., Jager, N., \& Newig, J. (2015). What Is Sustainable Agriculture? A Systematic Review. Sustainability, 7, 7833-7865. https://doi.org/10.3390/su7067833.

Willett, W., Rockström, J., Loken, B., Springmann, M., Lang, T., Vermeulen, S., Garnett, T., Tilman, D., DeClerck, F., Wood, A., Jonell, M., Clark, M., Gordon, L.J., Fanzo, J., Hawkes, C., Zurayk, R., Rivera, J.A., De Vries, W., Majele Sibanda, L., ... Murray, C.J.L. (2019). Food in the Anthropocene: the EAT-Lancet Commission on healthy diets from sustainable food systems. The Lancet, 393(10170), 447-492. https://doi.org/10.1016/ S0140-6736(18)31788-4

Wines of Chile. (2016). Sustainability: Practice and commitment. Prochile, Santiago

Zúñiga-Venegas, L., Saracini, C., Pancetti, F., Muñoz-Quezada, M.T., Lucero, B., Foerster, C., \& Cortés, S. (2020). Pesticide exposure in Chile and population health: urgency for decision making. In Gaceta Sanitaria. Ediciones Doyma, S.L. https://doi.org/10.1016/j.gaceta.2020.04.020. 